Synthesis, Spectroscopic Characterization, Thermal Investigation and Antimicrobial Activity of $\mathrm{S}, \mathrm{O}$ and N-Donor Heterocyclic Schiff Base Ligands and their $\mathrm{Co}(\mathrm{II}), \mathrm{Cd}(\mathrm{II}), \mathrm{Hg}(\mathrm{II}), \mathrm{Fe}(\mathrm{III})$ and $\mathrm{UO}_{2}$ (II) Metal Complexes

\author{
Zeinab A. El-Shafiey \\ Chemistry Department, Faculty of Science, (Girls') Al-Azhar \\ University, Nasr City, Cairo, P.O. Box 11754, Egypt.
}

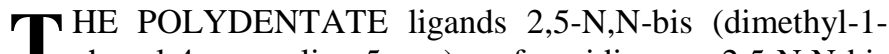
phenyl-4-pyrazoline-5-one) furanidine; 2,5-N,N-bis (pyridine) furanidine and 2,5-N,N-bis (2-thiophenol) furanidine $\left(\mathrm{L}^{1}-\mathrm{L}^{3}\right)$, have been prepared and identified. The chemical behavior of these ligands towards some metal cations such as $\mathrm{Co}(\mathrm{II}) \mathrm{Cd}(\mathrm{II}), \mathrm{Hg}(\mathrm{II}), \mathrm{Fe}(\mathrm{III})$ and $\mathrm{UO}_{2}$ (II) was studied. The isolated complexes are characterized using analytical data, IR, ${ }^{1} \mathrm{H}-\mathrm{NMR}$, UV-visible, mass spectroscopy, magnetic susceptibility, thermal analysis and molar conductance measurements. Bonding of the ligands with the metal ions is deduced from IR spectra and the presence of the mononuclear complexes are inferred from the mass spectral study. An octahedral structure is proposed for the prepared metal complexes and some ligand field parameters $\left(D_{4}, B\right.$, and $\left.\beta\right)$ in addition to LFSE were calculated from electronic spectral data. All synthesized compounds were screened for their antimicrobial activity against gram positive and gram negative bacteria and fungi. The biological evalution study showed high to moderate bacterial activity compared with the ligands, their metal complexes and known antibiotics data.
\end{abstract}

Keywords: Heterocyclic ligands, Metal complexes, Thermal studies and Antimicrobial activity.

The condensation of primary amines with carbonyl compounds are referred to as Schiff bases ${ }^{(1-4)}$. Schiff bases play an important role in inorganic chemistry as they easily form stable complexes with most transition metal ions ${ }^{(5)}$. A large number of Schiff bases and their complexes have been investigated for their interesting and important properties, especially they possess a diverse spectrum of biological and pharmaceutical activities such as antitumor and antioxidative activities. In continuation of our studies on the ligating properties of Schiff base ${ }^{(6-8)}$, it is necessary to synthesis $\mathrm{Co}(\mathrm{II}), \mathrm{Cd}$ (II), $\mathrm{Hg}(\mathrm{II}), \mathrm{Fe}(\mathrm{III})$ and $\mathrm{UO}_{2}$ (II) complexes of heterocyclic ligands; 
- 2,5-N,N-bis(2,3-dimethyl-1-phenyl-4-pyrazoline-5-one) furanidine, $\mathrm{L}^{1}$.

- 2,5-N,N-bis(1-thiophenol) furanidine, $\mathrm{L}^{2}$.

- 2,5-N,N-bis(pyridine) furanidine, $\mathrm{L}^{3}$.

The structural chemistry of the ligands and their complexes is the aim of this manuscript in addition to test whether any of synthesized compounds would prove to be effective in controlling the growth of a new important bacteria and fungi in attempt to understand the influence of metal ion/ligand nature on the biological properties.

\section{Reagents and instruments}

\section{Experimental}

All chemical used are of Analar grade and obtained from Fluka, Sigma, Aldrich, Merck and BDH. They include $\mathrm{Co}\left(\mathrm{CH}_{3} \mathrm{COO}\right)_{2} \cdot 4 \mathrm{H}_{2} \mathrm{O} ; \mathrm{Cd}\left(\mathrm{NO}_{3}\right)_{2} \cdot 4 \mathrm{H}_{2} \mathrm{O} ; \mathrm{Hg}\left(\mathrm{CH}_{3} \mathrm{COO}\right)_{2}$; $\mathrm{Fe}\left(\mathrm{NO}_{3}\right)_{3} \cdot 9 \mathrm{H}_{2} \mathrm{O} \quad \mathrm{UO}_{2}\left(\mathrm{NO}_{3}\right)_{2} \cdot 6 \mathrm{H}_{2} \mathrm{O}$; succinic anhydride; 4-aminoantipyrine; 2aminothiophenol; 2-aminopyridine, ethyl alcohol; diethylether, dimethyl formamide (DMF) and dimethyl sulfoxide (DMSO). Concentrated nitric acid and perchloric acid are reagent grade and used as supplied.

Elemental analyses (C, H, N, S) were carried out in Microanalytical Center at Cairo University. Metal contents were determined complexometrically ${ }^{(9)}$ by standard EDTA titration. Melting or decomposition points were carried out on a melting point apparatus, Gallenkamp, England. IR spectra were recorded on a Perkin-Elmer FT-IR type 1650 spectrophotometer using $\mathrm{KBr}$ discs, ${ }^{1} \mathrm{H}-\mathrm{NMR}$ spectra were recorded using Brucker ARX-300 spectrometer using DMSO- $\mathrm{d}_{6}$ as a solvent, chemical shifts are reported in parts per million downfield from tetramethylsilane. Mass spectra were recorded in a range of $\mathrm{m} / \mathrm{z}$ ratio between 0 and 1000 at Jeol JMSAX-500 mass spectrometer. Electronic spectra of solutions of ligand, and its metal complexes in DMF and the solid reflectance spectra were recorded on a Jasco model V-550 UV-Vis spectrophotometer, magnetic susceptibilities of the metal complexes were measured by the Gouy method at room temperature using a Johnson Matthey, Alpha products, model MKI magnetic susceptibility balance, the effective magnetic moments were calculated using the relation $\mu_{\text {eff }}=2.828\left(\chi_{\mathrm{m}} \cdot \mathrm{T}\right)^{1 / 2}$ B.M., where $\chi_{\mathrm{m}}$ is the molar susceptibility corrected using Pascal's constants for diamagnetism of all atoms in the compounds. The molar conductance measurements were performed in solutions of the complexes in DMF $\left(10^{-3} \mathrm{M}\right)$ using WTWD-812 Weilheium Conductivity meter model LBR, fitted with a cell model LTA100. A Shimadzu TGA-50H thermal analyzer was used to record simultaneously TG and DTG curves, the experiments were carried out in dynamic nitrogen atmosphere $\left(20 \mathrm{ml} . \mathrm{min}^{-1}\right)$ with a heating rate of $\left.10^{\circ} \mathrm{C} \mathrm{min}{ }^{-1}\right)$ in the temperature range $20-1000^{\circ} \mathrm{C}$ using platinum crucibles. Highly sintered $\alpha$ $\mathrm{Al}_{2} \mathrm{O}_{3}$ was used as a reference. The antimicrobial activity of ligands and their metal complexes were screened using the diffusion agar technique ${ }^{(10)}$ at the Medical Mycology Laboratory in the Regional Center for Mycology and Biotechnology at AL-Azhar University.

Egypt. J. Chem. 53, No. 1 (2010) 
Synthesis of the organic ligands

The Schiff base ligands under study, $\mathrm{L}^{1}-\mathrm{L}^{3}$ were obtained by condensation of succinic anhydride and the appropriate amines (4-amino- antipyrine; 2aminothiophenol and 2-aminopyridine) with continuous stirring in 1:2 molar ratios, respectively in presence of few drops of pipredine in ehtanolic solution for $6 \mathrm{hr}$ in a water bath then cooled. After cooling, the product was filtered off, recrystallized from ethanol, washed with diethyl ether and finally dried in a desiccator over anhydrous calcium chloride. The proposed structure of the ligands, (Fig. 1) is in a good agreement with the stoichiometry concluded from their analytical data (Table 1).<smiles>Cc1c(N=C2CCC(Nc3c(C)n(C)n(-c4ccccc4)c3=O)O2)c(=O)n(-c2ccccc2)n1C</smiles>

2.5-N, N-bis (2, 3-dimethyl-1-phenyl-4-pyrazoline-5-one) furanidine.<smiles>Sc1ccccc1/N=C1\CC/C(=N\c2ccccc2S)O1</smiles>

2, 5-N, N-bis (1-thiophenol) furanidine<smiles>c1ccc(/N=C2\CC/C(=N\c3ccccn3)O2)nc1</smiles>

2, 5-N, N-bis (pyridine) furanidine

Fig.1. Structure, name and abbreviation of Ligands, $\mathrm{L}^{1}-\mathrm{L}^{3}$

Synthesis of the metal complexes

The metal complexes were prepared by adding slowly a hot ethanolic solution of the appropriate metal salt $(0.01 \mathrm{~mol})$ namely; $\mathrm{Co}\left(\mathrm{CH}_{3} \mathrm{COO}\right)_{2} \cdot 4 \mathrm{H}_{2} \mathrm{O}$, $\mathrm{Cd}\left(\mathrm{NO}_{3}\right)_{2} \cdot 4 \mathrm{H}_{2} \mathrm{O}, \mathrm{Hg}\left(\mathrm{CH}_{3} \mathrm{COO}\right)_{2}, \quad \mathrm{Fe}\left(\mathrm{NO}_{3}\right)_{3} .9 \mathrm{H}_{2} \mathrm{O}$ and $\mathrm{UO}_{2}\left(\mathrm{NO}_{3}\right)_{2} \cdot 6 \mathrm{H}_{2} \mathrm{O}$ to ethanolic solution of the respective ligands, $\mathrm{L}^{1}-\mathrm{L}^{3}(0.01 \mathrm{~mol})$. The reaction mixture was stirred and refluxed for $2 \mathrm{hr}$ on water bath. The formed solid complexes (1 -15) that separated out were filtered, washed with ethanol and diethyl ether then dried in a desiccators over anhydrous calcium chloride. The isolated complexes (1 -15) are powder, stable in air, soluble in DMF and DMSO, insoluble in most organic solvents and their elemental analysis are in accordance with the proposed stoichiometry and agree well with the suggested molecular 
formula. The analytical data of the metal complexes together with their physical properties are summarized in Table 1.

\section{Results and Discussion}

The reaction of ligands under study, $\mathrm{L}^{1}-\mathrm{L}^{3}$ with $\mathrm{Co}(\mathrm{II}), \mathrm{Cd}(\mathrm{II}), \mathrm{Hg}(\mathrm{II}), \mathrm{Fe}(\mathrm{III})$, and $\mathrm{UO}_{2}$ (II) ions afforded the mononuclear metal complexes (1-15). The structure of the isolated complexes are discussed on the basis of their elemental analysis, conductance, IR, electronic spectral data, mass spectra and magnetic moment measurements. The obtained data are listed in Table 1.

$\mathrm{ML}(\mathrm{Xy})_{\mathrm{n}} \mathrm{Z}$

$(1-15)$

\begin{tabular}{|c|c|c|c|c|c|c|}
\hline $\begin{array}{c}\text { No. of } \\
\text { Compounds }\end{array}$ & $\mathbf{L}$ & M & $\mathrm{X}$ & $\mathbf{Y}$ & $\mathbf{n}$ & $\mathbf{Z}$ \\
\hline 1 & $\mathrm{~L}^{1}$ & Co (II) & OAc & - & 2 & $3.5 \mathrm{H}_{2} \mathrm{O}$ \\
\hline 2 & $\mathrm{~L}^{1}$ & Cd (II) & $\mathrm{NO}_{3}$ & - & 2 & $1.75 \mathrm{H}_{2} \mathrm{O}$ \\
\hline 3 & $\mathrm{~L}^{1}$ & Hg (II) & OAc & - & 2 & $2 \mathrm{H}_{2} \mathrm{O}$ \\
\hline 4 & $\mathrm{~L}^{1}$ & Fe (III) & $\mathrm{NO}_{3}$ & - & 2 & $\mathrm{NO}_{3} .2 \mathrm{H}_{2} \mathrm{O}$ \\
\hline 5 & $\mathrm{~L}^{1}$ & $\mathrm{UO}_{2}$ (II) & $\mathrm{NO}_{3}$ & $\mathrm{H}_{2} \mathrm{O}$ & 1 & $\mathrm{NO}_{3}$ \\
\hline 6 & $\mathrm{~L}^{2}$ & Co (II) & OAc & - & 2 & $4 \mathrm{H}_{2} \mathrm{O}$ \\
\hline 7 & $\mathrm{~L}^{2}$ & Cd (II) & $\mathrm{NO}_{3}$ & $\mathrm{H}_{2} \mathrm{O}$ & 1 & $\mathrm{NO}_{3} .1 .5 \mathrm{H}_{2} \mathrm{O}$ \\
\hline 8 & $\mathrm{~L}^{2}$ & Hg (II) & OAc & $\mathrm{H}_{2} \mathrm{O}$ & 1 & OAc. $\mathrm{H}_{2} \mathrm{O}$ \\
\hline 9 & $\mathrm{~L}^{2}$ & $\mathrm{Fe}$ (III) & $\mathrm{NO}_{3}$ & - & 2 & $\mathrm{NO}_{3} .1 .5 \mathrm{H}_{2} \mathrm{O}$ \\
\hline 10 & $\mathrm{~L}^{2}$ & $\mathrm{UO}_{2}$ (II) & $\mathrm{NO}_{3}$ & - & 2 & $2.25 \mathrm{H}_{2} \mathrm{O}$ \\
\hline 11 & $\mathrm{~L}^{3}$ & Co (II) & OAc & - & 2 & $2.75 \mathrm{H}_{2} \mathrm{O}$ \\
\hline 12 & $\mathrm{~L}^{3}$ & Cd (II) & $\mathrm{NO}_{3}$ & - & 2 & $2 \mathrm{H}_{2} \mathrm{O}$ \\
\hline 13 & $\mathrm{~L}^{3}$ & Hg (II) & OAc & - & 2 & $2.5 \mathrm{H}_{2} \mathrm{O}$ \\
\hline 14 & $\mathrm{~L}^{3}$ & $\mathrm{Fe}$ (III) & $\mathrm{NO}_{3}$ & - & 2 & $\mathrm{NO}_{3} \cdot \mathrm{H}_{2} \mathrm{O}$ \\
\hline 15 & $\mathrm{~L}^{3}$ & $\mathrm{UO}_{2}$ (II) & $\mathrm{NO}_{3}$ & - & 2 & $\mathrm{H}_{2} \mathrm{O}$ \\
\hline
\end{tabular}

Molar conductivity measurements

The molar conductance measurements are recorded for $10^{-3} \mathrm{M}$ solution of the metal complexes in DMF at room temperature. Table 1 showed that the metal complexes, (1-3, 6, 10-13,15) fall in the expected range of non-electrolytes while the complexes, $(4,5,7-9,14)$ behave as $1: 1$ electrolyte $^{(11-13)}$.

Egypt. J. Chem. 53, No. 1 (2010) 


\begin{tabular}{|c|c|c|c|c|c|c|c|c|c|c|c|c|c|}
\hline \multirow{2}{*}{\multicolumn{2}{|c|}{ 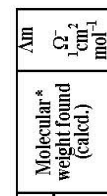 }} & . & $\simeq$ & ๙े & $\approx$ & $:$ & 8 & . & $=$ & $\infty$ & $\because$ & 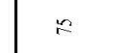 & 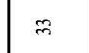 \\
\hline & & 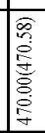 & 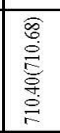 & 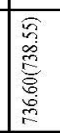 & 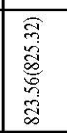 & 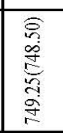 & 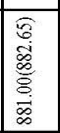 & 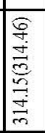 & 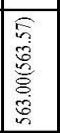 & 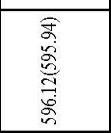 & 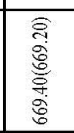 & 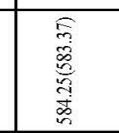 & 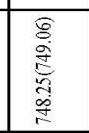 \\
\hline \multirow{5}{*}{ 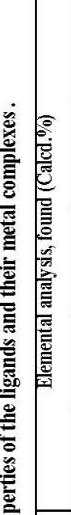 } & $z$ & . & 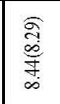 & 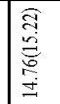 & $\begin{array}{l}\text { 高 } \\
\text { 总 } \\
\text { and }\end{array}$ & $\begin{array}{l}\text { 景 } \\
\text { dy }\end{array}$ & . & . & 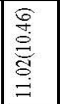 & 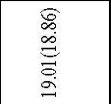 & 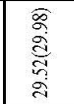 & 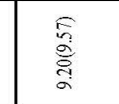 & \\
\hline & $\infty$ & . & . & . & . & & & 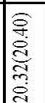 & 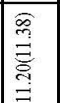 & 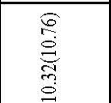 & 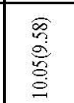 & 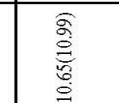 & 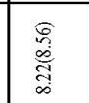 \\
\hline & z & $\mid$\begin{tabular}{|l}
$\overline{\bar{\alpha}}$ \\
$\overline{\bar{\sigma}}$ \\
$\bar{\sigma}$
\end{tabular} & 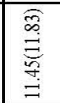 & 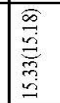 & 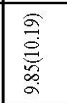 & 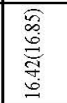 & 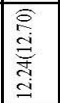 & 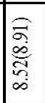 & 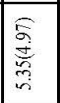 & 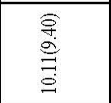 & 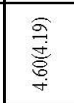 & 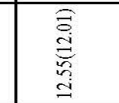 & 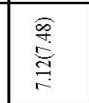 \\
\hline & I & 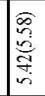 & 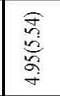 & 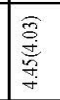 & 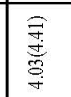 & 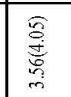 & 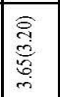 & \begin{tabular}{|l|l}
$\bar{y}$ \\
$\frac{y}{y}$ \\
$\frac{\partial}{y}$
\end{tabular} & 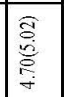 & 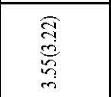 & 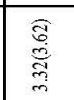 & $\begin{array}{l}\text { 蒿 } \\
\text { ğ }\end{array}$ & 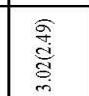 \\
\hline & 0 & 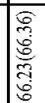 & \begin{tabular}{|l}
$\hat{8}$ \\
$\hat{0}$ \\
$\overline{0}$ \\
$\bar{n}$
\end{tabular} & 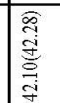 & 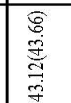 & $\begin{array}{l}\widehat{\widehat{a}} \\
\text { 吾 } \\
\exists\end{array}$ & 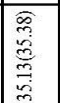 & 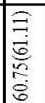 & 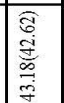 & 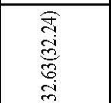 & 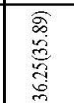 & 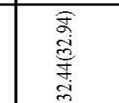 & 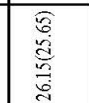 \\
\hline & ث0 & 屑 & 志 & \& & $\underset{ }{P}$ & $\stackrel{\leftrightarrow}{g}$ & $\stackrel{\infty}{\exists}$ & $\not$ & Io & 해 & $\Xi$ & क् & 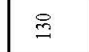 \\
\hline & 흥 & 囍 & 栕言 & 总 & 善害 & 善喜 & 害 & 胥 & 善 & है & 兽 & 鄫 & 咅 \\
\hline & 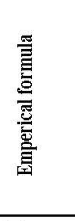 & 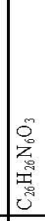 & 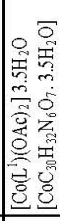 & 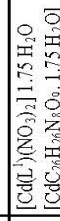 & 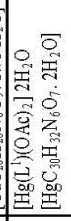 & 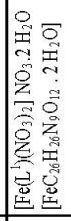 & 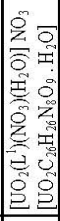 & 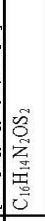 & 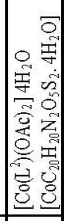 & 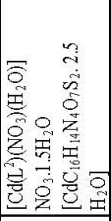 & 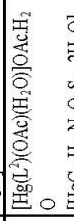 & 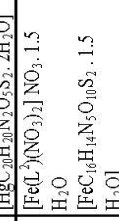 & 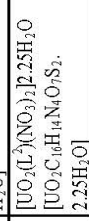 \\
\hline & 言竞 & $\Rightarrow$ & - & . & m & + & $n$ & $\because$ & 0 & - & $\infty$ & o & $\cong$ \\
\hline
\end{tabular}

Egypt. J. Chem. 53, No. 1 (2010) 


\begin{tabular}{|c|c|c|c|c|c|c|}
\hline 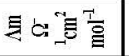 & . & $n$ & $\therefore$ & $\approx$ & 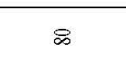 & $\Rightarrow$ \\
\hline 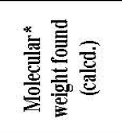 & 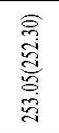 & 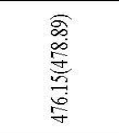 & 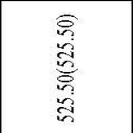 & 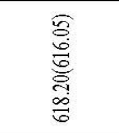 & 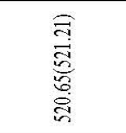 & 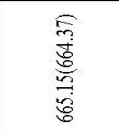 \\
\hline $\bar{z}$ & . & 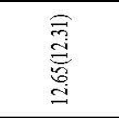 & 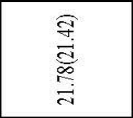 & 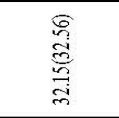 & 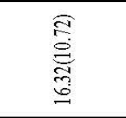 & . \\
\hline$\infty$ & ${ }^{\prime}$ & $\cdot$ & 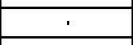 & 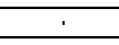 & $\cdot$ & I \\
\hline$z$ & $\begin{array}{l}\text { สี } \\
\text { चु }\end{array}$ & 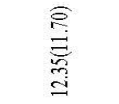 & 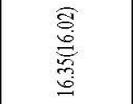 & 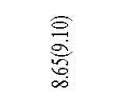 & 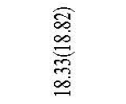 & 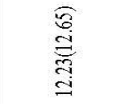 \\
\hline$=$ & 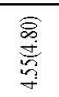 & 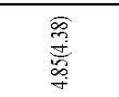 & 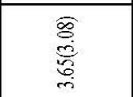 & 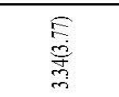 & 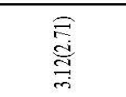 & 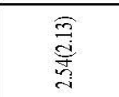 \\
\hline 0 & 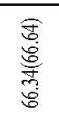 & 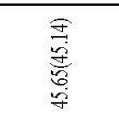 & $\begin{array}{l}\text { 总 } \\
\text { 站 } \\
\text { 离 }\end{array}$ & 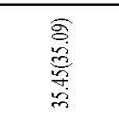 & 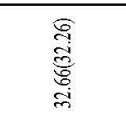 & 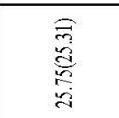 \\
\hline 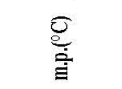 & $\Xi$ & 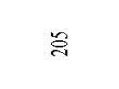 & $\Phi$ & 롯 & $\Xi$ & હ્રે \\
\hline 흥 & 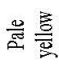 & 善 & 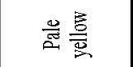 & 㞼 & 善器 & 衰 \\
\hline 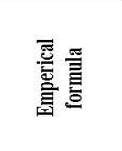 & $\begin{array}{l}\text { 올 } \\
\text { 章 } \\
\text { 章 }\end{array}$ & 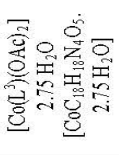 & 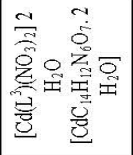 & 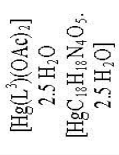 & 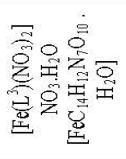 & 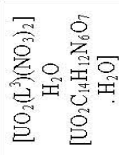 \\
\hline 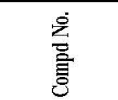 & $\Rightarrow$ & $\Rightarrow$ & $\simeq$ & $=$ & \pm & $\simeq$ \\
\hline
\end{tabular}


${ }^{1} H$ NMR spectra

The spectrum of the ligand, $\mathrm{L}^{1}$ shows strong signals at $\delta 2.8 \mathrm{ppm}(3 \mathrm{H}, \mathrm{s}), \delta 3.8$ ppm $(3 \mathrm{H}, \mathrm{s})$ and $\delta 7.6-7.3 \mathrm{ppm}$ (multiplets) these signals are attributed to $\mathrm{C}-$ $\mathrm{CH}_{3}, \mathrm{~N}-\mathrm{CH}_{3}$ and aromatic protons, respectively ${ }^{(14)}$. The spectra of the ligand, $\mathrm{L}^{2}$ shows a signal at about $\delta 3.4 \mathrm{ppm}(1 \mathrm{H}, \mathrm{s})$ attributed to $\mathrm{SH}$ protons ${ }^{(15,16)}$, this signal in metal complexes, $(7,8)$ is shifted to up or/and downfield which indicates that the SH group may participate in coordination without proton displacement. The spectra of the ligand, $\mathrm{L}^{3}$ show signal due to pyridine protons at $\delta 7.9-6.3 \mathrm{ppm}$ (multiplets) ${ }^{(1)}$. In metal complexes, $(12,13)$, the upfield shift of these signals suggest the participation of pyridine nitrogen in coordination to the metal ions.

\section{IR spectra}

Vibrational bands of the free ligands and their complexes are given in Table 2. The reaction of succinic anhydride with different amines forms imino compounds, the $v \mathrm{C}=\mathrm{O}$ and $v \mathrm{NH}_{2}$ are replaced by $v \mathrm{C}=\mathrm{N}$ bands. The spectra of all ligands exhibited strong sharp band at $1682-1606 \mathrm{~cm}^{-1}$ which was previously assigned to $\mathrm{C}=\mathrm{N}$ azomethine group ${ }^{(17)}$. In all metal complexes this band is shifted to lower frequency region $1666-1524 \mathrm{~cm}^{-1}$ inferring the involvement of the azomethine nitrogen in coordination. Also, a strong band was observed at $1188-1156 \mathrm{~cm}^{-1}$ attributed to $\mathrm{vC}-\mathrm{O}-\mathrm{C}$ of heteorcyclic ring which remains almost unaffected in complexes indicating its non-participation in coordination ${ }^{(18,19)}$. IR spectrum of ligand, $\mathrm{L}^{1}$ shows a very strong band at 1652 $\mathrm{cm}^{-1}$ and another medium band at $1140 \mathrm{~cm}^{-1}$ which may be attributed to $v \mathrm{C}=\mathrm{O}$ and $v \mathrm{~N}-\mathrm{N}$ of antipyrinyl moiety, respectively ${ }^{(6)}$. The spectra of metal complexes, $(1-5)$ show a considerable negative shift in the carbonyl absorption $(\mathrm{C}=\mathrm{O})$ at $1642-1606 \mathrm{~cm}^{-1}$ indicating that carbonyl oxygen is involved in coordination. IR spectrum of the ligand, $\mathrm{L}^{2}$ shows a very weak band at $2600 \mathrm{~cm}^{-1}$ corresponding to $v(\mathrm{~S}-\mathrm{H})$ which is shifted to lower frequency in the spectra of the complexes, (6-10). This indicates that coordination takes place through the sulphur atom without deprotonation. Moreover, the absorption due to $v$ (C-S) of the ligand, $\mathrm{L}^{2}$ at $752 \mathrm{~cm}^{-1}$ is shifted to higher or / and lower frequency regions at $764-738 \mathrm{~cm}^{-1}$ in metal complexes, (6-10) indicating that the other coordination is through phenolic sulphur atom ${ }^{(20,21)}$. IR spectrum of the ligand, $\mathrm{L}^{3}$ exhibited two characteristic bands at 1566 and $968 \mathrm{~cm}^{-1}$ assigned to pyridine ring vibration and pyridine ring breathing mode ${ }^{(22)}$. The spectra of metal complexes, (11-15) show that these bands are shifted to lower frequency at $1550-1418 \mathrm{~cm}^{-1}$ and 888$818 \mathrm{~cm}^{-1}$, respectively indicating the involvement of pyridine ring nitrogen in coordination. The presence of water molecules coordinated or/and lattice were observed in some complexes by a broad band observed at about $3556-3354 \mathrm{~cm}^{-1}$ ${ }^{(23)}$. IR spectra of metal complexes reveal newly medium and / or weak bands at $698-528 \mathrm{~cm}^{-1}, 590-460 \mathrm{~cm}^{-1}$ and $468-425 \mathrm{~cm}^{-1}$ assigned to $v \mathrm{M}-\mathrm{O}, v \mathrm{M}-\mathrm{N}$ and $v \mathrm{M}-\mathrm{S}$, respectively ${ }^{(6,20)}$. These new bands indicate a good evidence for the participation of $\mathrm{O}, \mathrm{S}$ and $\mathrm{N}$ donors in complex formation. Additionally, the position of $v_{\text {asy }}$ (OCO) and $v_{\mathrm{sy}}$ (OCO) bands at $1575-1436 \mathrm{~cm}^{-1}$ and $1375-$ $1208 \mathrm{~cm}^{-1}$, respectively in the IR spectra of acetato complexes, $(1,3,6,8,11,13)$ 
as well as their difference, $\Delta>185 \mathrm{~cm}^{-1}$ are characteristic for the monodentate coordination mode ${ }^{(24)}$. The nitrato complexes, $(2,10,12,15)$ show three bands at $1492-1404 \mathrm{~cm}^{-1}, 1374-1234 \mathrm{~cm}^{-1}$ and $1170-1026 \mathrm{~cm}^{-1}$ corresponding to unidentate coordination mode of nitrate group while the complexes, $(4,5,7,9$, 14) have a characteristic strong absorption band at $1384-1382 \mathrm{~cm}^{-1}$ and medium band at $815-764 \mathrm{~cm}^{-1}$ assigned to ionic nitrate, additionally complexes $(4,5,7,9,14)$ show three bands at $1485-1442 \mathrm{~cm}^{-1}, 1296-1200 \mathrm{~cm}^{-1}$ and 1166 $-1020 \mathrm{~cm}^{-1}$ corresponding to unidentate coordination mode of nitrate group ${ }^{(25-}$

27). All these results are consistent with the conductance data. The IR spectra of uranyl complexes, $(5,10,15)$ show strong absorption bands in the region $930-$ $922 \mathrm{~cm}^{-1}$ assigned to the antisymmetric $v_{3}(\mathrm{O}=\mathrm{U}=\mathrm{O})$ vibration ${ }^{(5,23,28)}$.

Magnetic moments and electronic spectra

The room temperature magnetic moments and electronic spectral data of the metal complexes are listed in Table 3. the magnetic moments values; $4.86-4.75$ and 5.76 - 5.60 B.M for cobalt (II) and Fe(III) complexes, respectively. These data are close to that reported for three and five unpaired electrons. Cd(II), $\mathrm{Hg}(\mathrm{II})$ and $\mathrm{UO}_{2}$ (II) complexes are diamagnetic as expected for $\mathrm{d}^{10}$ system $^{(1,29,30)}$.

The electronic spectra of the ligands under study in DMF solution exhibit mainly three absorption bands in the region $46296-33557 \mathrm{~cm}^{-1}$. The first and second peaks are assigned to $\pi-\pi^{*}$ transitions within the phenyl or / and heterocyclic ring and imino $\pi-\pi^{*}$ transition, while the third peak arises from $\mathrm{n}-\pi^{*}$ transition involving electron migration along the entire conjugate system of the ligands. Upon complexation, these transitions were found to be shifted to lower or higher energy regions compared to the free ligands confirming the coordination of the ligands to metal ions, in addition to appearance of new bands at longer wavelength may be assigned to LMCT and d-d transitions ${ }^{(26)}$.

The solid reflectance spectra of Co(II) complexes (1,6 and 11) show three electronic spectral bands in the regions 9500 - 9100, $18201-17334$ and $19280-$ $18565 \mathrm{~cm}^{-1}$ may be assigned to ${ }^{4} \mathrm{~T}_{1 \mathrm{~g}}(\mathrm{~F}) \longrightarrow{ }^{4} \mathrm{~T}_{2 \mathrm{~g}}(\mathrm{~F})\left(v_{1}\right),{ }^{4} \mathrm{~T}_{1 \mathrm{~g}}(\mathrm{~F}) \longrightarrow{ }^{2} \mathrm{~A}_{2 \mathrm{~g}}(\mathrm{~F})$ $\left(v_{2}\right)$, and ${ }^{4} \mathrm{~T}_{1 \mathrm{~g}}(\mathrm{~F}) \longrightarrow{ }^{4} \mathrm{~T}_{2 \mathrm{~g}}(\mathrm{P})\left(v_{3}\right)$ transitions, respectively of the $\mathrm{d}^{7}$-system suggesting Co(II) high-spin complexes of octahedral geometry ${ }^{(7,20)}$. The ligand field parameters $\left(D_{q}, B\right.$ and $\beta$ ) where $D_{q}$ is the crystal field splitting parameter, $B$ the Racah interelectronic repulsion parameter and $\beta$ is the nephelauxtic parameter were calculated ${ }^{(31)}$. The smaller $\mathrm{B}$ value $\left(812-768 \mathrm{~cm}^{-1}\right)$ compared to the free metal ion $\left(971 \mathrm{~cm}^{-1}\right)$ is due to the strong interaction between the reactive sites of the organic compound with cobalt (II) ion which indicate a reduction of about $21-16 \%$ from the free ion value, also $(\beta)$ value is less than unity $(0.84-$ 0.79) suggesting a largely covalent bond between the organic ligand and cobalt (II) ion in these complexes. Additionally, the crystal field stabilization energy (CFSE) for octahedral Co(II) was calculated.

Egypt. J. Chem. 53, No. 1 (2010) 


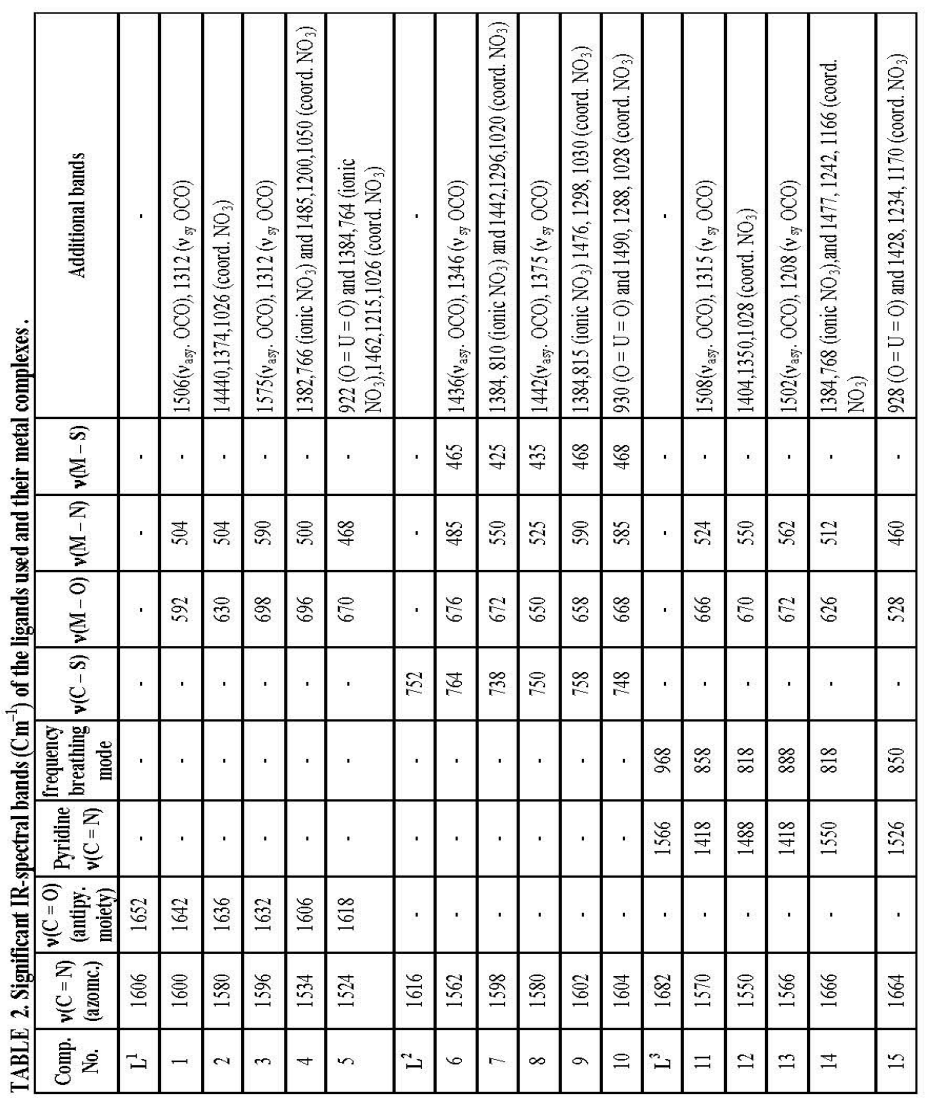

Egypt. J. Chem. 53, No. 1 (2010) 


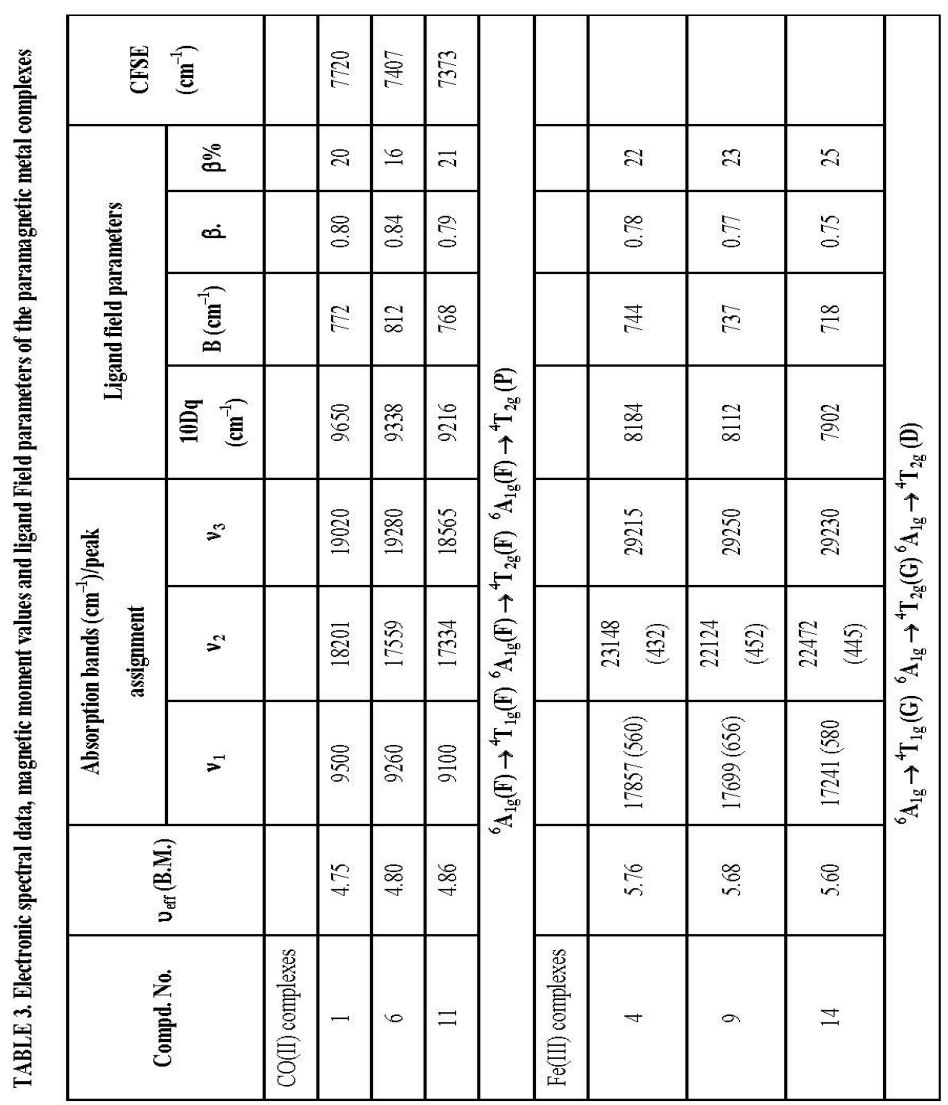

Egypt. J. Chem. 53, No. 1 (2010) 
The electronic spectra of Fe(III) complexes, (4, 9 and 14) display three absorption bands in the regions 17857 - 17241, 23148 - 22124 and 29250 $29215 \mathrm{~cm}^{-1}$ may be assigned to ${ }^{6} \mathrm{~A}_{1 \mathrm{~g}} \longrightarrow{ }^{4} \mathrm{~T}_{1 \mathrm{~g}}(\mathrm{G})\left(v_{1}\right),{ }^{6} \mathrm{~A}_{1 \mathrm{~g}} \longrightarrow{ }^{4} \mathrm{~T}_{2 \mathrm{~g}}(\mathrm{G})\left(v_{2}\right)$, and ${ }^{6} \mathrm{~A}_{1 \mathrm{~g}} \longrightarrow{ }^{4} \mathrm{~T}_{2 \mathrm{~g}}(\mathrm{D})\left(v_{3}\right)$ transitions, respectively, these results together with measured magnetic moments are compatible with those reported for octahedral geometry around $\mathrm{Fe}(\mathrm{III})$ ions ${ }^{(32)}$. The ligand field parameters $\left(\mathrm{D}_{\mathrm{q}}, \mathrm{B}\right.$ and $\beta$ ) were calculated ${ }^{(33,34)}$. The smaller B value $\left(744-718 \mathrm{~cm}^{-1}\right)$ compared to the free metal ion $\left(960 \mathrm{~cm}^{-1}\right)$ is due to the strong interaction between the reactive sites of the organic compound with $\mathrm{Fe}(\mathrm{III})$ ion which indicate a reduction of about $25-22 \%$ from the free ion value, also $\beta$ is less than unity $(0.78-0.75)$ suggesting a largely covalent bond between the organic ligand and Fe(III) ion in these complexes.

Cd (II) complexes, (2,7 and 12), Hg(II) complexes, (3,8 and 13) and $\mathrm{UO}_{2}$ (II) complexes, (5,10 and 15) are diamagnetic and their electronic spectra exhibit an intense absorption band in the regions 30303-25126 $\mathrm{cm}^{-1}$ attributed to LMCT transition which is compatible with octahedral structure ${ }^{(26,35)}$.

A summary of the ligand field parameters data are given in Table 3 and agree well with those reported for similar complexes. From these investigation data, the suggested structure of the prepared complexes may be formulated as shown in Fig. 2-4 and is supported from mass spectra study.

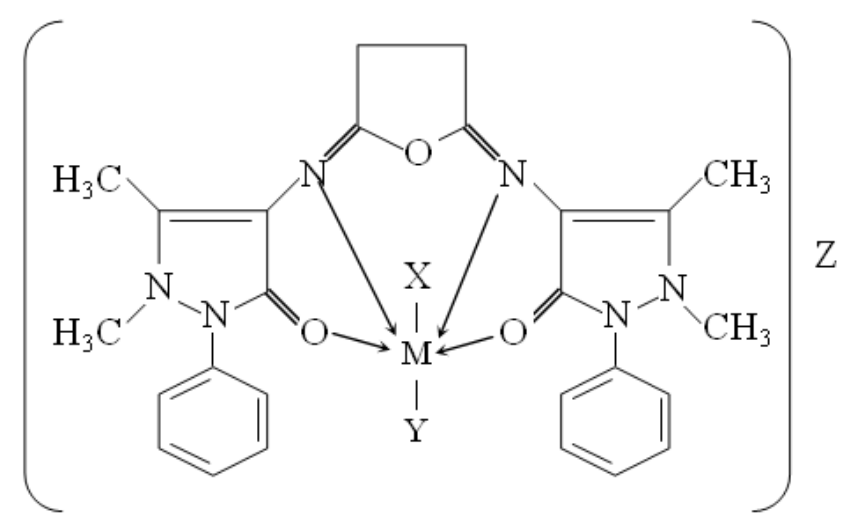

$$
\begin{aligned}
& \text { In complex (1): } \mathrm{M}=\mathrm{Co}\left(\text { II), } \mathrm{X}=\mathrm{Y}=\mathrm{OAC}, \mathrm{Z}=3.5 \mathrm{H}_{2} \mathrm{O}\right. \\
& \text { In complex (2): } \mathrm{M}=\mathrm{Cd}\left(\text { II), } \mathrm{X}=\mathrm{Y}=\mathrm{NO}_{3}, \mathrm{Z}=1.75 \mathrm{H}_{2} \mathrm{O}\right. \\
& \text { In complex (3): } \mathrm{M}=\mathrm{Hg}\left(\text { II), } \mathrm{X}=\mathrm{Y}=\mathrm{OAC} \mathrm{Z}=2 \mathrm{H}_{2} \mathrm{O}\right. \\
& \text { In complex (4): } \mathrm{M}=\mathrm{Fe}\left(\text { III), } \mathrm{X}=\mathrm{Y}=\mathrm{NO}_{3}, \mathrm{Z}=\mathrm{NO}_{3} \cdot 2 \mathrm{H}_{2} \mathrm{O}\right. \\
& \text { In complex (5): } \mathrm{M}=\mathrm{UO}_{2} \text { (II); } \mathrm{X}=\mathrm{NO}_{3}, \mathrm{Y}=\mathrm{H}_{2} \mathrm{O} ; \mathrm{Z}=\mathrm{NO}_{3}
\end{aligned}
$$

Fig. 2. Proposed structure of metal complexes of ligand, $L^{1}$. 


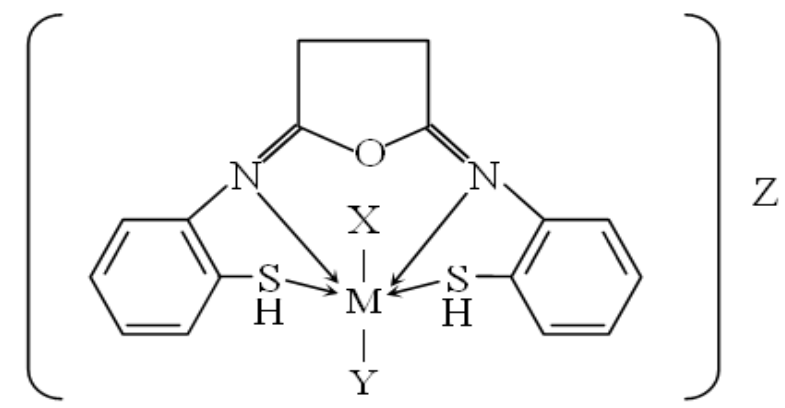

In complex (6): $\mathrm{M}=\mathrm{Co}\left(\right.$ II), $\mathrm{X}=\mathrm{Y}=\mathrm{OAC}, \mathrm{Z}=4 \mathrm{H}_{2} \mathrm{O}$ In complex (7): $\mathrm{M}=\mathrm{Cd}(\mathrm{II}), \mathrm{X}=\mathrm{NO}_{3} ; \mathrm{Y}=\mathrm{H}_{2} \mathrm{O}, \mathrm{Z}=\mathrm{NO}_{3} .1 .5 \mathrm{H}_{2} \mathrm{O}$ In complex (8): $\mathrm{M}=\mathrm{Hg}(\mathrm{II}), \mathrm{X}=\mathrm{OAC} ; \mathrm{Y}=\mathrm{H}_{2} \mathrm{O} ; \mathrm{Z}=\mathrm{OAC} \cdot \mathrm{H}_{2} \mathrm{O}$ In complex (9): $\mathrm{M}=\mathrm{Fe}(\mathrm{III}), \mathrm{X}=\mathrm{Y}=\mathrm{NO}_{3}, \mathrm{Z}=\mathrm{NO}_{3} .1 .5 \mathrm{H}_{2} \mathrm{O}$ In complex (10): $\mathrm{M}=\mathrm{UO}_{2}(\mathrm{II}) ; \mathrm{X}=\mathrm{Y}=\mathrm{NO}_{3} ; \mathrm{Z}=2.25 \mathrm{H}_{2} \mathrm{O}$

Fig. 3. Proposed structure of metal complexes of ligand, $L^{2}$.

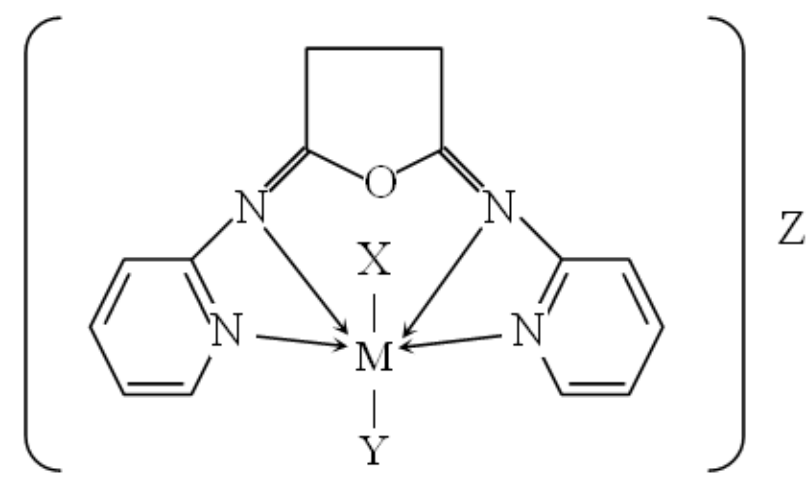

In complex (11): $\mathrm{M}=\mathrm{Co}(\mathrm{II}), \mathrm{X}=\mathrm{Y}=\mathrm{OAC} ; \mathrm{Z}=2.75 \mathrm{H}_{2} \mathrm{O}$

In complex (12): $\mathrm{M}=\mathrm{Cd}(\mathrm{II}), \mathrm{X}=\mathrm{Y}=\mathrm{NO}_{3} ; \mathrm{Z}=2 \mathrm{H}_{2} \mathrm{O}$

In complex (13): $\mathrm{M}=\mathrm{Hg}(\mathrm{II}), \mathrm{X}=\mathrm{Y}=\mathrm{OAC} ; \mathrm{Z}=2.5 \mathrm{H}_{2} \mathrm{O}$

In complex (14): $\mathrm{M}=\mathrm{Fe}(\mathrm{III}), \mathrm{X}=\mathrm{Y}=\mathrm{NO}_{3} ; \mathrm{Z}=\mathrm{NO}_{3} \cdot \mathrm{H}_{2} \mathrm{O}$

In complex (15): $\mathrm{M}=\mathrm{UO}_{2}(\mathrm{II}) ; \mathrm{X}=\mathrm{Y}=\mathrm{NO}_{3} ; \mathrm{Z}=\mathrm{H}_{2} \mathrm{O}$

Fig. 4. Proposed structure of metal complexes of ligand, $L^{3}$. 


\section{Mass spectra}

The mass spectra of the ligands, $\mathrm{L}^{1}-\mathrm{L}^{3}$ and their $\mathrm{Co}(\mathrm{II}), \mathrm{Cd}(\mathrm{II}), \mathrm{Hg}(\mathrm{II})$, $\mathrm{Fe}(\mathrm{III})$, and $\mathrm{UO}_{2}$ (II) complexes were performed to determine their molecular weights. The mass spectra of the free ligands confirm the proposed formula by showing the mole peaks at $\mathrm{m} / \mathrm{z}=470.00$ (10.12\%), $313.15(12.52 \%)$ and 253.05 (10.78\%) amu (calcd. 470.58, 314.46 and 252.30 amu), respectively corresponding to the molecular ion $[\mathrm{M}]^{+} ; \mathrm{C}_{26} \mathrm{H}_{26} \mathrm{~N}_{6} \mathrm{O}_{3}, \mathrm{C}_{16} \mathrm{H}_{14} \mathrm{~N}_{2} \mathrm{OS}_{2}$ and $\mathrm{C}_{14} \mathrm{H}_{12} \mathrm{~N}_{4} \mathrm{O}$, respectively. Their proposed fragmentation pattern is depicted in Fig. 5-7. In the mass spectra of the metal complexes, (1-15) Table 1 showed the molecular ion peak $[\mathrm{M}]^{+}$corresponding to the molecular weight of the complexes for mononuclear structure. Scheme 1 shows the proposed fragmentation pattern of the Co (II) complexes as representative example.

\section{Thermogravimetric analysis}

Thermal analysis plays an important role in studying the properties of metal complexes to obtain a useful data on the metal-ligand bonds. The thermal decomposition of all metal complexes (1-15) was studied using the TGtechnique. During the heating of the metal complexes, the TG-curves undergo a series of thermal changes associated with a weight loss of the samples. Analysis of the obtained TG-curves is given in Table 4 and the correlations between the different decomposition steps of the complexes with the corresponding weight losses are discussed in terms of the proposed formula of the complexes. Figure 8 is a representative example for thermal analysis of the metal complexes under study.

\section{Antibacterial and antifungal screening}

All synthesized compounds; the free ligands $\mathrm{L}^{1}-\mathrm{L}^{3}$, and their $\mathrm{Co}(\mathrm{II}), \mathrm{Cd}(\mathrm{II})$, $\mathrm{Hg}(\mathrm{II}), \mathrm{Fe}(\mathrm{III})$ and $\mathrm{UO}_{2}(\mathrm{II})$ complexes have been tested against four species of bacteria; S. aureus; E.coli; B.subtilis and P.aeruginosa as well as three species of fungi; A. fumigatus; P.italicum and C.albicans. The test was done using diffusion agar technique ${ }^{(10)}$ and both Chloramphenicol and Terbinafin were used as standard antibacterial and antifungal agents, respectively. The compounds to be tested were dissolved in dimethyl formamide at different concentration 1, 2.5 and $5 \mathrm{mg} / \mathrm{ml}$ and the diameter $(\mathrm{cm})$ of the inhabitation zone was measured, all data were collected in Table 5 .

On comparing the biological activity of the Schiff base ligands and their metal complexes the following results are obtained:

(1) The ligands and their metal complexes, all have the capacity of inhibiting the metabolic growth of the investigated bacteria and fungi to different extent. This inhibitory capacity is reinforced with the increment of concentration. 


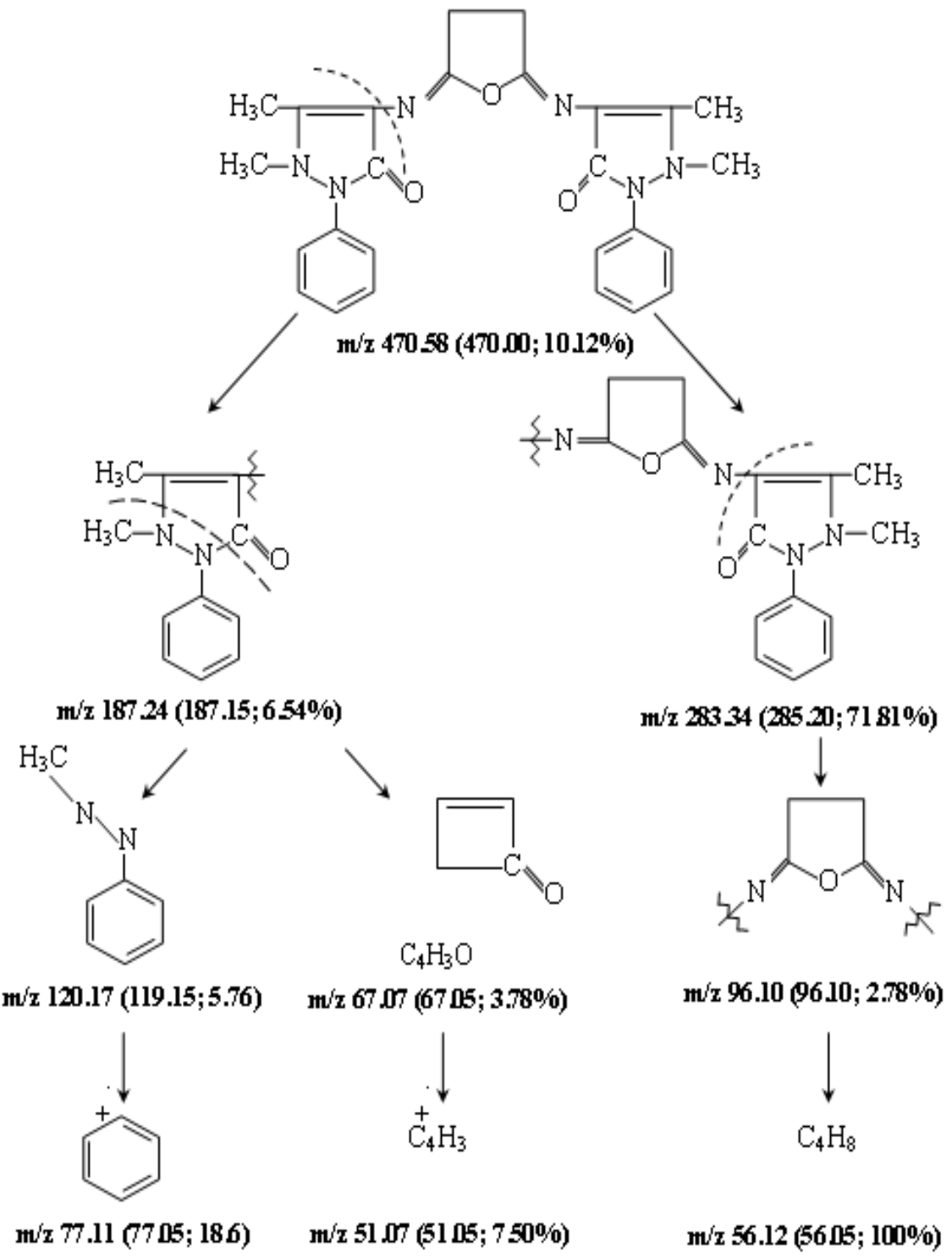

Fig. 5. Proposed structure of metal complexes of ligand, $L^{1}$. 


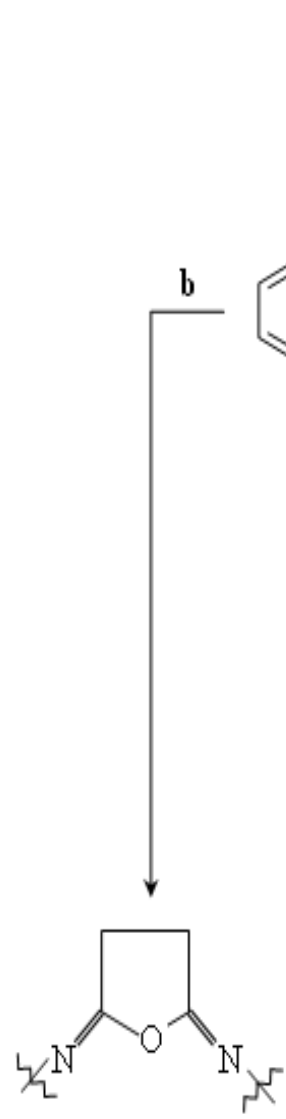

$\mathrm{m} / \mathrm{z} 96.1(97.05 ; 5.01 \%)$<smiles>c1ccoc1</smiles>

$\mathrm{m} / \mathrm{z} 72.12(73.10 ; 2.23 \%)$

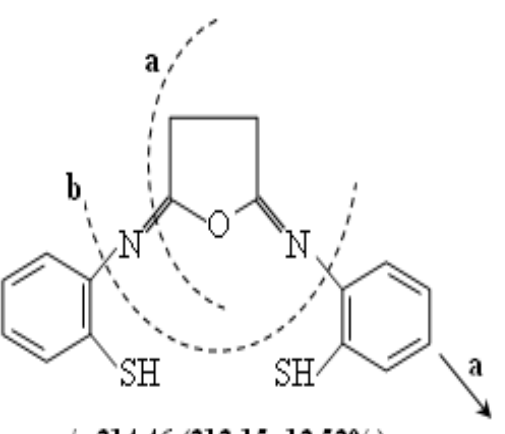

$\mathrm{m} / \mathrm{z} 314.46(313.15 ; 12.52 \%)$<smiles>CN(C)c1ccccc1S</smiles>

$\mathrm{m} / \mathrm{z} 123.19(124.10 ; 48.51 \%)$

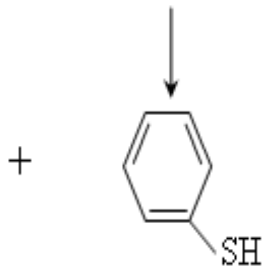

$\mathrm{m} / \mathrm{z} 191.27(190.05 ; 7.26 \%)$

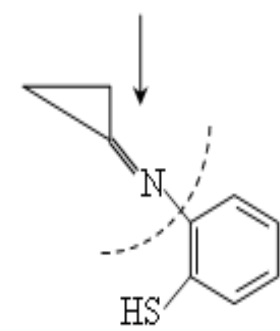

$\mathrm{m} / \mathrm{z} 109.18(109.10 ; 12.43 \%) \quad \mathrm{m} / \mathrm{z} 163.26(162.05 ; 100.00 \%)$
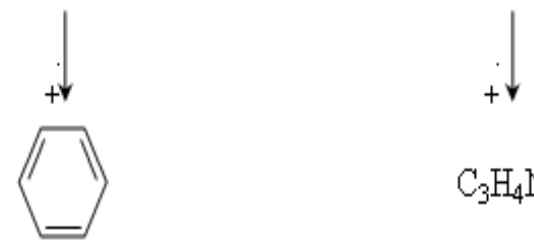

$\mathrm{C}_{3} \mathrm{H}_{4} \mathrm{~N}$

Fig. 6. Proposed structure of metal complexes of ligand, $L^{2}$. 


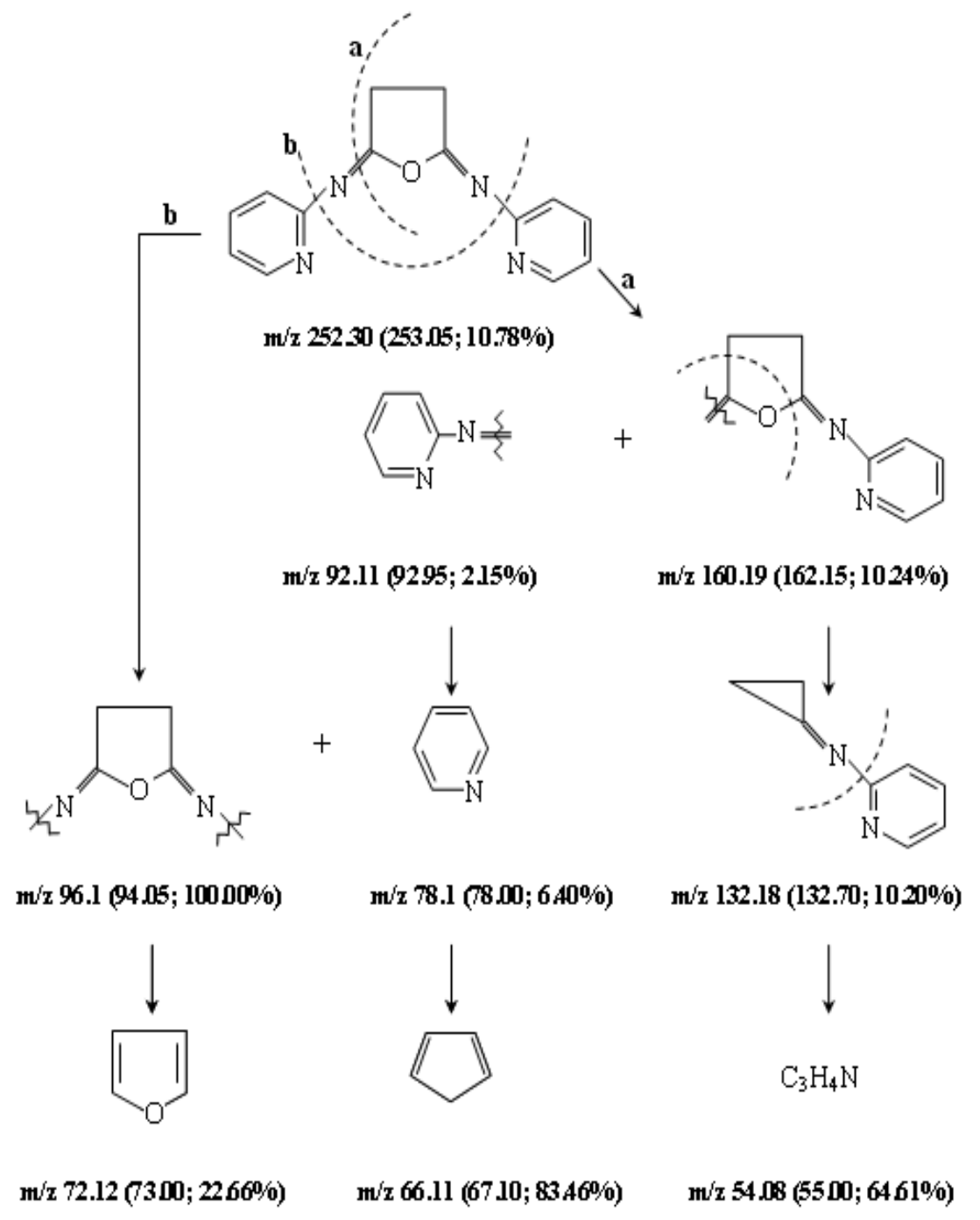

Fig. 7. Proposed structure of metal complexes of ligand, $L^{3}$. 

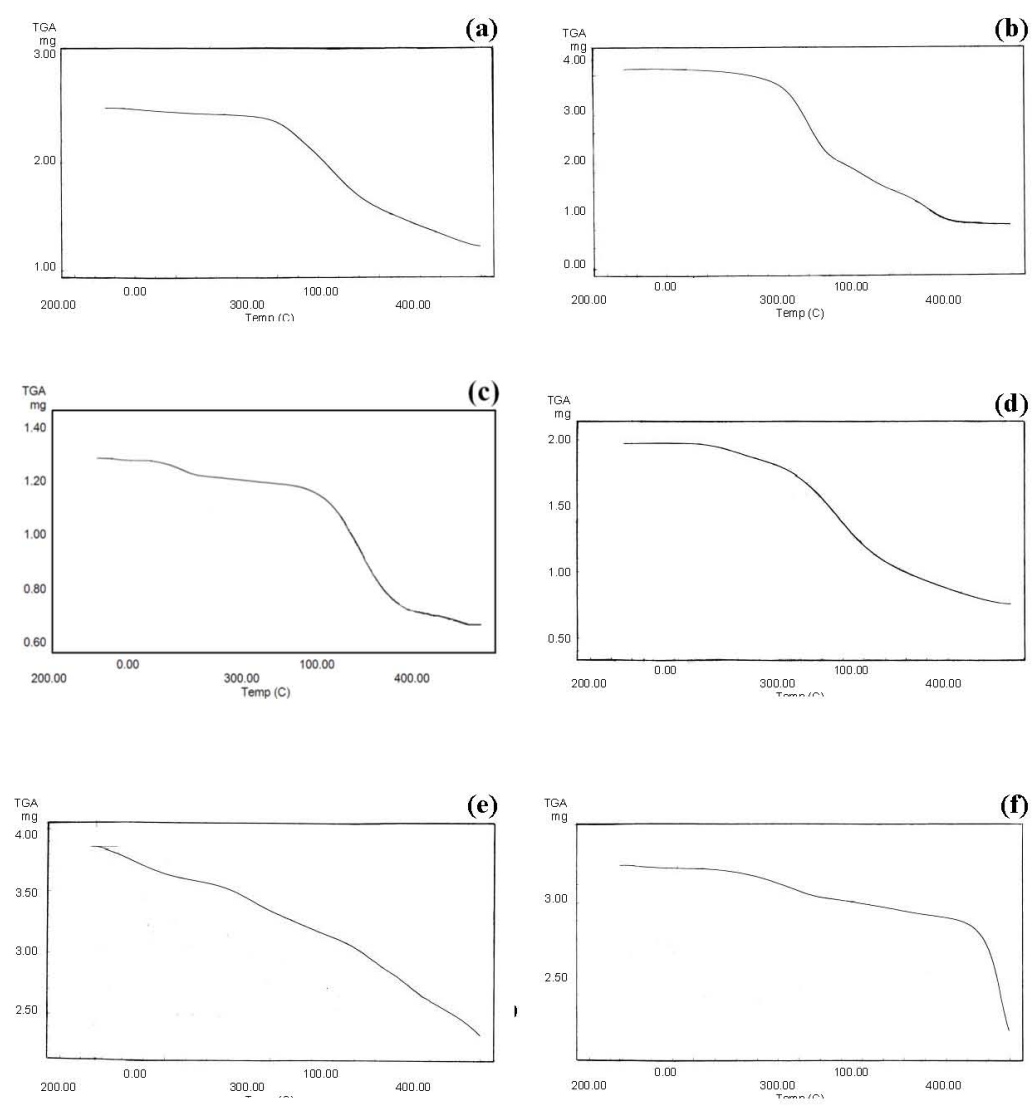

Fig.8. TG curves of: (a) $\left[\mathrm{Co}\left(\mathrm{L}^{1}\right)(\mathrm{OAc})_{2}\right] 3.5 \mathrm{H}_{2} \mathrm{O}$.
(b) $\left[\mathrm{Hg}\left(\mathrm{L}^{1}\right)(\mathrm{OAc})_{2}\right] 2 \mathrm{H}_{2} \mathrm{O}$.
(c) $\left[\mathrm{Co}\left(\mathrm{L}^{2}\right)(\mathrm{OAc})_{2}\right] 4 \mathrm{H}_{2} \mathrm{O}$
(d) $\left[\mathrm{Hg}\left(\mathrm{L}^{2}\right)(\mathrm{OAc})\left(\mathrm{H}_{2} \mathrm{O}\right] . \mathrm{OAc} \cdot \mathrm{H}_{2} \mathrm{O}\right.$.
(e) $\left[\mathrm{Co}\left(\mathrm{L}^{3}\right)(\mathrm{OAc})_{2}\right] 2.75 \mathrm{H}_{2} \mathrm{O}$
(f) $\left[\mathrm{Hg}\left(\mathrm{L}^{3}\right)(\mathrm{OAc})_{2}\right] 2.5 \mathrm{H}_{2} \mathrm{O}$. 


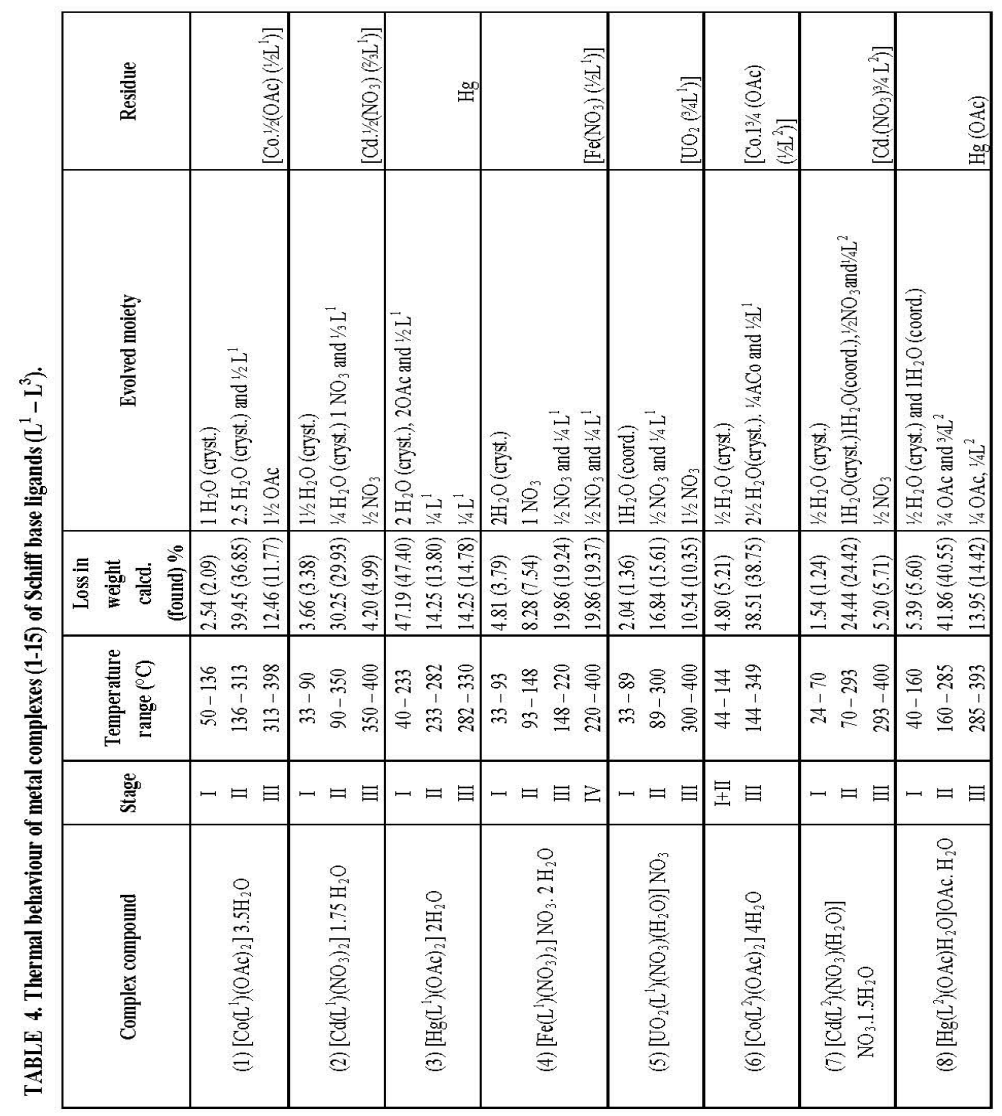

Egypt. J. Chem. 53, No. 1 (2010) 


\begin{tabular}{|c|c|c|c|c|c|c|c|}
\hline $\begin{array}{l}\text { 善 } \\
\text { 产 }\end{array}$ & 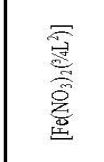 & . & 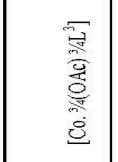 & $z$ & 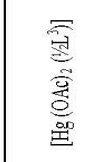 & $\underset{\tilde{c}}{\overrightarrow{0}}$ & $\begin{array}{l}\frac{\overline{3}}{\frac{3}{2}} \\
\frac{3}{5} \\
\overline{8}\end{array}$ \\
\hline 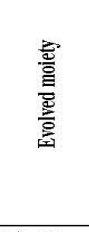 & 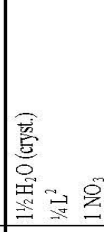 & 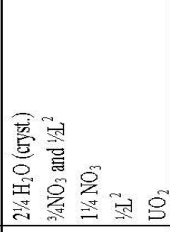 & 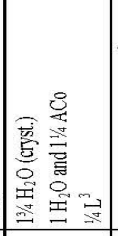 & 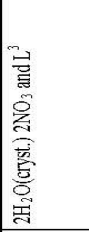 & 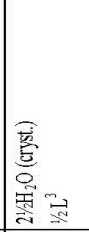 & 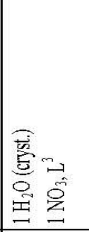 & 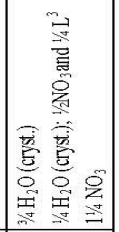 \\
\hline 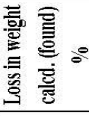 & 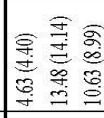 & 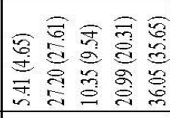 & 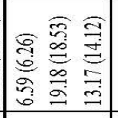 & 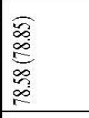 & 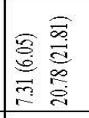 & 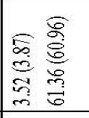 & 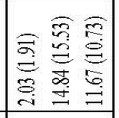 \\
\hline 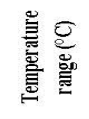 & 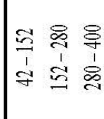 & 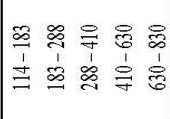 & 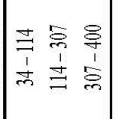 & $\frac{\infty}{7}$ & 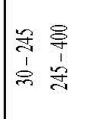 & 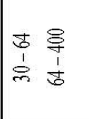 & 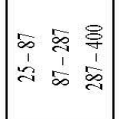 \\
\hline 彎 & 至目己 & ー・曰 $\geq>$ & 一旺豈 & - & 圼目 & $\neg \equiv$ & -日曰 \\
\hline 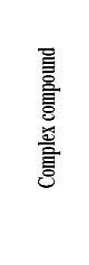 & 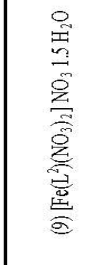 & 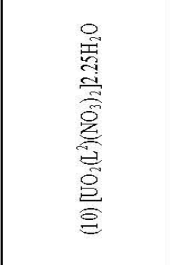 & 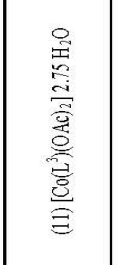 & 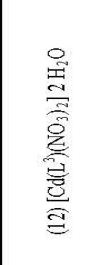 & 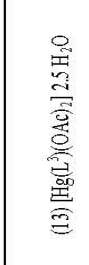 & 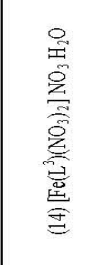 & 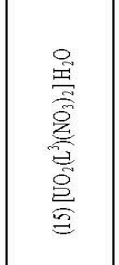 \\
\hline
\end{tabular}

Egypt. J. Chem. 53, No. 1 (2010) 
TABLE 5. Antibacterial and antifungal activity of the ligands and their metal complexes.

\begin{tabular}{|c|c|c|c|c|c|c|c|c|c|c|c|c|c|c|c|c|c|c|c|c|c|}
\hline Strain & & hylocon & & Eseh & ererchia & & Batil & IIus sul & & & uldomor & & & & & & enicilliti & & & andida & \\
\hline mompdiml & 5 & 2.5 & 1 & 5 & 2.5 & 1 & 5 & 2.5 & 1 & 5 & 2.5 & 1 & 5 & 2.5 & 1 & 5 & 2.5 & 1 & 5 & 2.5 & 1 \\
\hline $\mathbf{L}^{1}$ & H++ & ++ & + & +t & + & 0 & + & 0 & 0 & ++ & + & 0 & +++ & ++ & + & +++ & ++ & + & H+ & ++ & + \\
\hline 1 & t+ & ++ & t+ & ++ & t+ & + & ++ & t+ & + & t+ & + & + & +++ & t+ & + & t+t+ & ++ & + & H+t & ++ & + \\
\hline 2 & +++ & ++ & + & +++ & ++ & + & +++ & ++ & + & +++ & ++ & + & +++ & ++ & + & + & 0 & 0 & H++ & ++ & + \\
\hline 3 & ++ & ++ & + & + & + & 0 & ++ & + & 0 & + & + & 0 & ++ & ++ & + & ++ & + & 0 & + & + & 0 \\
\hline 4 & ++ & ++ & + & H & + & 0 & ++ & + & 0 & + & + & 0 & ++ & t+ & + & ++ & ++ & + & ++ & t+ & 0 \\
\hline 5 & + & + & 0 & + & + & 0 & + & 0 & 0 & + & + & 0 & + & + & 0 & + & + & 0 & + & + & 0 \\
\hline & & & + & & & & & + & & & & & & & & & & & & & \\
\hline $\mathrm{L}^{2}$ & ++ & ++ & + & + & 0 & 0 & + & + & 0 & + & + & 0 & ++ & t+ & 0 & ++ & + & 0 & ++ & t+ & + \\
\hline 6 & ++ & ++ & + & +++ & ++ & + & +++ & ++ & + & +++ & ++ & + & +++ & ++ & + & +++ & ++ & + & ++ & ++ & + \\
\hline 7 & +++ & ++ & + & ++ & ++ & + & ++ & + & + & ++ & + & + & +++ & ++ & + & +++ & ++ & + & + & 0 & 0 \\
\hline 8 & ++ & ++ & + & H & ++ & + & ++ & ++ & + & H & + & + & ++ & + & + & ++ & + & 0 & ++ & + & 0 \\
\hline 9 & + & 0 & 0 & + & 0 & 0 & + & 0 & 0 & + & 0 & 0 & + & 0 & 0 & + & 0 & 0 & + & 0 & 0 \\
\hline 10 & ++ & ++ & 0 & H & + & 0 & ++ & + & 0 & H & + & 0 & + & 0 & 0 & ++ & + & 0 & + & 0 & 0 \\
\hline & & + & & & & & & & & & & & & & & & & & & & \\
\hline$L^{3}$ & + & + & 0 & + & 0 & 0 & + & + & 0 & + & + & 0 & + & + & 0 & ++ & + & 0 & + & 0 & 0 \\
\hline 11 & ++ & ++ & + & ++ & ++ & + & ++ & t+ & + & ++ & t+ & 0 & + & + & + & t++ & ++ & + & H++ & ++ & + \\
\hline 12 & $\mathrm{H+}$ & ++ & + & +++ & t+ & + & +++ & ++ & + & +++ & t+ & + & +++ & ++ & + & +++ & ++ & + & + & 0 & 0 \\
\hline 13 & ++ & ++ & + & H & + & + & ++ & + & 0 & H & + & + & ++ & + & + & ++ & + & 0 & ++ & + & 0 \\
\hline 14 & + & + & 0 & + & 0 & 0 & + & 0 & 0 & + & 0 & 0 & + & 0 & 0 & + & 0 & 0 & + & 0 & 0 \\
\hline 15 & ++ & + & 0 & H & + & 0 & ++ & + & 0 & + & + & 0 & + & 0 & 0 & ++ & 0 & 0 & ++ & + & 0 \\
\hline R.S. & ++ & ++ & H & H+ & ++ & ++ & H+t & +++ & H & +++ & +++ & ++ & +++ & +++ & H & $1+++$ & +++ & +t+ & +t+ & ++ & ++ \\
\hline
\end{tabular}

The test was done using the diffusion agar technique. Well diameter $=0.6 \mathrm{~cm}$; inhibition values $=0.1-0.5 \mathrm{~cm}$ beyond control $=+$ (less active); inhibition values $=0.6-1.0 \mathrm{~cm}$ beyond control $=++$ (moderate active) inhibition values $=1.1-1.5 \mathrm{~cm}$ beyond control $=+++$ (highly active), not active $(0)$

St: reference standard; chloramphenicol was used as a standard antibacterial agent and Terbinafin was used as a standard antifungal agent. 
TABLE 6. Antibacterial activity of some known antibiotics .

\begin{tabular}{|c|c|c|c|}
\hline Antibiotic name & $\begin{array}{c}\text { Staphylococcus } \\
\text { aureus }\end{array}$ & $\begin{array}{c}\text { Pseudomonase } \\
\text { aeruguinosa }\end{array}$ & Escherichia coli \\
\hline Amikacin & $\mathrm{R}$ & +++ & ++ \\
Doxycillin & +++ & $\mathrm{R}$ & $\mathrm{R}$ \\
Augmantin & +++ & $\mathrm{R}$ & +++ \\
Sulperazon & +++ & +++ & $\mathrm{R}$ \\
Unasyn & +++ & $\mathrm{R}$ & ++ \\
Septrin & $\mathrm{R}$ & $\mathrm{R}$ & $\mathrm{R}$ \\
Cefobid & $\mathrm{R}$ & $\mathrm{R}$ & $\mathrm{R}$ \\
Ampicillin & $\mathrm{R}$ & ++ & ++ \\
Nitrofurantion & +++ & $\mathrm{R}$ & $\mathrm{R}$ \\
Traivid & $\mathrm{R}$ & $\mathrm{R}$ & +++ \\
Erythromycin & +++ & $\mathrm{R}$ & $\mathrm{R}$ \\
\hline $\mathrm{R}=$ resistance to the microorganism & &
\end{tabular}

$\mathrm{R}=$ resistance to the microorganism

(2)The ligand, $\mathrm{L}^{1}$ was found to be more effective against bacteria; S.aureus, E.coli and p. aeruginosa and all types of fungi, A. fumigatus; p.italicum and C.albicans as compared to the other ligands, $\left(\mathrm{L}^{2}\right.$ and $\left.\mathrm{L}^{3}\right)$ whih may due to the antipyrinyl ring. Its influence is highly active towards S.aureus, A.fumigatus, p.italicum and C.albicans, moderately active towards E.coli and p.aeruginosa.

(3) The ligands, $\mathrm{L}^{2}$ and $\mathrm{L}^{3}$ have the same effect towards the tested organisms except ligand, $\mathrm{L}^{2}$ is moderately active towards S.aureus and all types of fungi.

(4) The activity of the free ligands is enhanced on chelation with metal ions, this enhancement in activity can be explained on the basis of chelation theory ${ }^{(14,36)}$.

(5) On comparison the activity of metal complexes for each ligand alone shows that: Cd(II) complex,(2) was found to be more effective against all types of bacteria and fungi except p.italicum as compared to the other complexes, (1,3-5), also Cd(II) complexes $(7,12)$ had more effective except against C.albicans as compared to the complexes $(6,8-10)$ and $(11,13-15)$.

(6) The Co(II) complexes, (1,6 and 11) for all ligands, $\mathrm{L}^{1}-\mathrm{L}^{3}$ were found to be highly active towards all types of fungi and moderatly active towards all types of bacteria. This may be due to the presence of acetate anion which may be helpfull in the activity of these complexes.

Comparison of the antibacterial activity of the synthesized compounds with some known antibiotics shows that metal complexes possess remarkable antimicrobial activity equal to or higher than some antibiotics possess as clear from Table 6. 


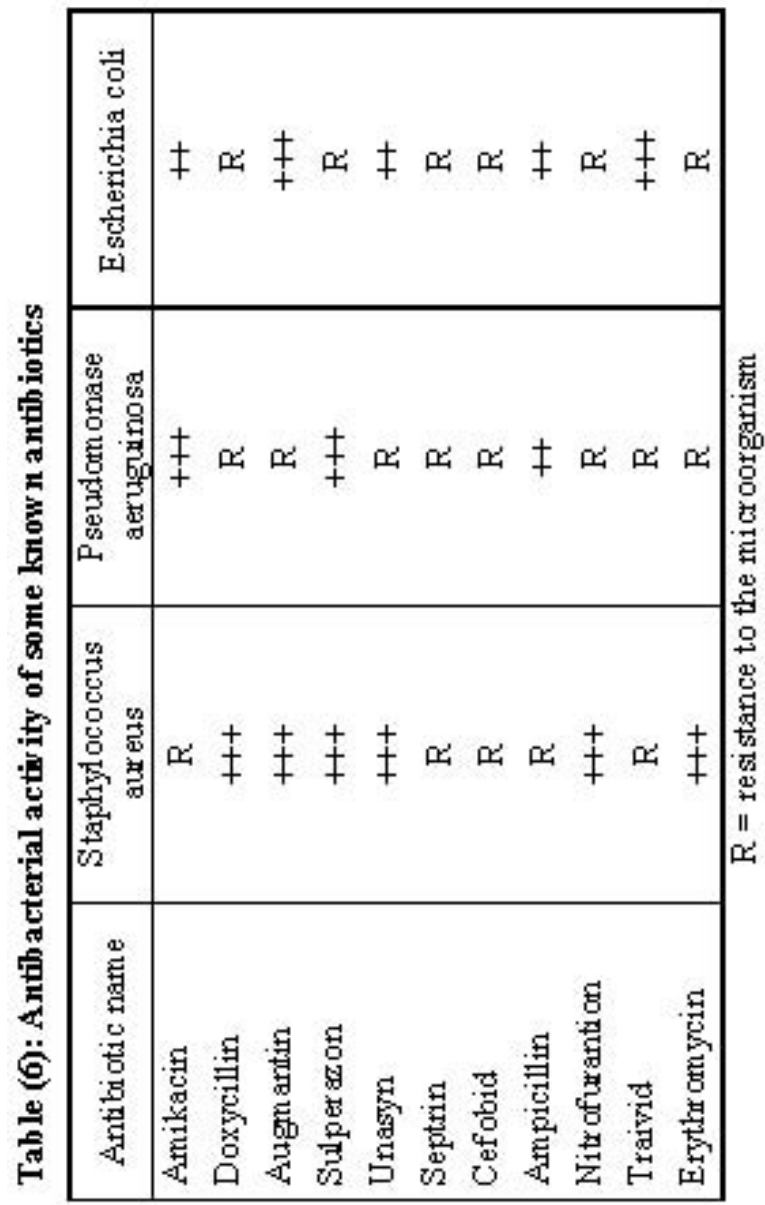

\section{Conclusion}

The present study aimed to investigate the reaction of heterocyclic ligands derived from condensation of succinic anhydride with 4-amino antipyrine; 2aminothiophenol and 2-aminopyridine with $\mathrm{Co}(\mathrm{II}), \mathrm{Cd}(\mathrm{II}), \mathrm{Hg}(\mathrm{II}), \mathrm{Fe}(\mathrm{III})$ and $\mathrm{UO}_{2}$ (II) ions. The structure of the synthesized compounds has been proposed via various physico-chemical techniques. As a result, the octahedral structure is proposed for these complexes and the ligands coordinate as teradentate ONNO, SNNS or NNNN donor ligands. The antimicrobial activity of the investigated ligands and their complexes was tested against different strains of bacteria and fungi and an influence of the central metal ion of the complexes is evident, where the results show that metal complexes have an enhanced activity compared to their parent ligands, furthermore, the activity of some complexes was found to be comparable with that of the standards materials.

Egypt. J. Chem. 53, No. 1 (2010) 


\section{References}

1. Gudasi, K.B., Patil, S.A., Vadavi, R.S., Shenoy, R.V. and Patil, M. S., Synthesis and spectral characterization of some transition metal complexes containing pentadentate SNNNS donor heterocyclic Schiff base ligands. Transition. Met. Chem. 30, 1014 (2005).

2. Ispir, E., Kurtoglu, M. and Toroglu, S., The d10 metal chelates derived from Schiff base ligands having silane: Synthesis, characterization, and antimicrobial studies of cadmium(II) and Zinc(II) complexes. Synth. React Inorg. Met.-Org. and Nano-Met. Chem. 36, 627 (2006).

3. Lv, J., Liu, T., Cai, S., Wang, X., Liu L. and Wang, Y., Synthesis, structure and biological activity of cobalt(II) and copper(II) complexes of valine-derived schiff bases. J. Inorg. Biochem. 100, 1888 (2006).

4. Golcu, A., Tumer, M., Demirelli, H. and Wheatley, R.A., Cd(II) and Cu(II) complexes of polydentate Schiff base ligands: synthesis, characterization, properties and biological activity. Inorg. Chim. Acta, 358, 1785 (2005).

5. El-Behery M. and El-Twigry, H., Synthesis, magnetic, spectral, and antimicrobial studies of $\mathrm{Cu}(\mathrm{II}), \mathrm{Ni}(\mathrm{II}) \mathrm{Co}(\mathrm{II}), \mathrm{Fe}(\mathrm{III})$, and $\mathrm{UO}_{2}(\mathrm{II})$ complexes of a new Schiff base hydrazone derived from 7-chloro-4-hydrazinoquinoline, Spectrochim. Acta, A66, 28 (2007).

6. Abd El-Wahab Z. H., Mashaly M.M. and Faheim, A.A., Synthesis and characterization of cobalt(II), cerium(III), and dioxouranium(VI) complexes of 2,3dimethyl-1-phenyl-4-salicylidene-3-pyrazolin-5-one mixed ligand complexes, pyrolytic products, and biological activities. chem.. Pap. 59, 25 (2005).

7. Mohamed, G.G. and Abd El-Wahab, Z.H., Mixed ligand complexes of bis (phenylimine) Schiff base ligands incorporating pyridinium moiethy synthesis, characterization and antibacterial activity. Spectrochim. Acta A61, 1059 (2005).

8. Mashaly, M.M., Abd El-Wahab, Z. H. and Faheim, A.A, Preparation, spectral characterization and antimicrobial activities of Schiff base complexes derived from 4aminoantipyrine. mixed ligand complexes with 2-aminopridine, 8-hydroxyquinoline and oxalic acid and their pyrolytical products. J. Chin. Chem. Soc. 51, 901 (2004).

9. Bassett, G., Denny, R. C., Geffery, G.H., Mendhan, J. Vogells Textbook of Quantitative Inorganic Analysis. $4^{\text {th }}$ ed (1982).

10. Raman, N. Ravichandran, S., Synthesis and characterization of a new Schiff base and its metal complexes derived from the mannich base, N-(1-piperidinobenzyl) acetamide. Synth. React. Inorg. Met. -org. and Nano-Met. Chem. 35, 439 (2005).

11. Ciobanu, A., Zalaru, F., Zalaru, C., Dumitrascu, F. and Draghici, C., Coordination compounds of $\mathrm{Cu}(\mathrm{II})$ with Schiff bases derived from formylmenthone and aromatic amines. Acta Chim. Solv. 50, 441 (2003). 
12. Ying, L.M., Zhi, H.P., Cheng, Z. J., Yi, L. and Xi, X. K., Study on synthesis and antibacterial activities of some new transition metal complexes with Schiff base ligand containing pyridine and amide moieties. Chin. J. Chem. 22, 162 (2004).

13. Shakir, M., Azim, Y., Chishti, H. T. N. and Parveen, S., Synthesis, characterization of complexes of $\mathrm{Co}(\mathrm{II}), \mathrm{Ni}(\mathrm{II}), \mathrm{Cu}(\mathrm{II})$ and $\mathrm{Zn}(\mathrm{II})$ with 12-membered Schiff base tetraazamacrocyclic ligand and the study of their antimicrobial and reducing power. Spectrochim. Acta, A65, 490 (2006).

14. Raman, N., Kulandaisamy, A., Thangaraja, C., Manisankar, P., Viswanathan, S. and Vedhi, C., Synthesis, structural characterisation and electrochemical and antibacterial studies of Schiff base copper complexes. Transition Met. Chem. 29, 129 (2004).

15. Oztas, S.G., Sahinb, E., Ancina, N., Ideb, S. and Tuzun, M., Structural and spectral studies of N-(3-hydroxypyridine-2-yl)-5-hydroxysalicylideneimine and its dimethyltin(IV) complex. J. Mol. Struct. 705, 107 (2004).

16. Soliman A.A., Thermogravimetric and spectroscopic studies on cadmium complexes with two salicylidene thiophenol schiff bases. J. Therm. Anal. Cal. 63, 221 (2001).

17. Ucan, S.Y. and Mercimek, B., Synthesis and characterization of tetradentate N2O2 schiff base ligands and their transition metal complexes. Synth. React. Inorg. Met.org. and Nano-Met. Chem. 35, 197 (2005).

18. El-Shafiey, Z.A., Dawy, M. and Abd El-Wahab Z. H., Synthesis, characterization and electrical studies of transition metal complexes containing heterocyclic ligand derived from 1-Phenyl-2, 3-dimrthyl-4-aminopyrazol-5-one and 2-Furfuraldehyde. AlAzhar Bull. Sci. Conf. 25-27, 241 (2003).

19. Srivastava, V., Srivastava, S.K. and Mishra, A.P., Complexes of cobalt(II), nickel(II) and copper(II) with furfurylidene-nicotinamide Schiff base. J. Indian Chem. Soc. 72, 47 (1995).

20. Panchal, P. K., Pansuriya, P. B. and Patel, M.N., In-vitro biological evaluation of some ONS and NS donor Schiff's bases and their metal complexes. J. Enzyme Inhib. and Medic. Chem. 21, 453 (2006).

21. Baysal, A. and Buldag, A., Synthesis and spectroscopic characterization of transition metal(II) complexes with a novel $\mathrm{N}_{2} \mathrm{O}_{2}$ donor ligand. Russ. J. Coord. Chem. 33, 190 (2007).

22. Gudasi, K.B., Patil, S. A., Vadavi, R. S., Shenoy R. V. and Patil, M. S., synthesis and spectral investigation of some transition metal complexes containing pentadentate macroacydic NNNNN-donor Schiff ligands . J. Transition Met. Chem. 30, 726 (2005).

23. Abd El-Wahab, Z. H., Mashaly, M.M., Salman, A. A., El-Shetary, B.A. and Faheim, A.A., $\mathrm{Co}(\mathrm{II}), \mathrm{Ce}(\mathrm{III})$ and $\mathrm{UO}_{2}(\mathrm{VI})$ bis-salicylatothiosemicarbazide complexes: Binary and ternary complexes, thermal studies and antimicrobial activity. Spectrochim. Acta, A60, 2861 (2004).

24. El-Shazly, R.M., Al-Hazmi, G.A.A., Ghazy, S.E., El-Shahawi, M.S. and El-Asmy, A.A., Spectroscopic, thermal and electrochemical studies on some nickel(II) thiosemicarbazone complexes. Spectrochim. Acta, A61, 243 (2005).

Egypt. J. Chem. 53, No. 1 (2010) 
25. Chandra, S. and Kumar, A., Spectral studies on $\mathrm{Co}(\mathrm{II})$, Ni(II) and $\mathrm{Cu}(\mathrm{II})$ complexes with thiosemicarbazone $\left(\mathrm{L}^{1}\right)$ and semicarbazone $\left(\mathrm{L}^{2}\right)$ derived from 2-acetyl furan. Spectrochimica Acta, A66, 1347 (2007).

26. Deepa, K., Madhu, N.T. and Radhakrishnan P.K.K., Cadmium(II) complexes of 1,2-Di(Imino- 4'-antipyrinyl)ethane. Synth. React. Inorg. Met.-org. and Nano-Met. Chem. 35, 883 (2005).

27. Abd El-Wahab, Z. H., Spectral and biological investigation of S O and N-donor heterocyclic ligands and their Co (II), Ni (II) Cd (II) and Fe (III) metal complexes. Al-Azhar Bull. Sci. 18, 15 (2007).

28. Badwaik, V.B. and Aswar, A.S., Synthesis, characterization and biological studies of some Sxhiff base complexes. Russ. J. Coord. Chem. 33, 755 (2007).

29. Abd El-Wahab, Z.H. and El-Sarrag, M.R., Derivatives of phosphate Schiff base transition metal complexes: synthesis, studies and biological activity. Spectrochim. Acta, 60, 271 (2004).

30. Chandra, S. and Gupta, L.K., Spectroscopic studies on $\mathrm{Co}(\mathrm{II}), \mathrm{Ni}(\mathrm{II})$ and $\mathrm{Cu}(\mathrm{II})$ complexes with a new macrocyclic ligand: 2,9-dipropyl-3,10-dimethyl-1,4,8,11tetraaza-5,7:12,14-dibenzocyclotetradeca-1,3,8,10-tetraene. Spectrochim. Acta, A61, 1181 (2005).

31. Mohamed, G.G.A. and El-Gamel N. E., Synthesis, investigation and spectroscopic characterization of piroxicam ternary complexes of $\mathrm{Fe}(\mathrm{II}), \mathrm{Fe}(\mathrm{III}), \mathrm{Co}(\mathrm{II}), \mathrm{Ni}(\mathrm{II})$, $\mathrm{Cu}(\mathrm{II})$ and $\mathrm{Zn}(\mathrm{II})$ with glycine and DL-phenylalanine. pectrochim. Acta, A60, 3141 (2004).

32. Nishat, N. and Haq, M.M., Synthesis and characterization of new macrocycles containing pendant groups. Synth. React. Inorg. Met.-org. and Nano-Met. Chem. 34, 335 (2005).

33. Rakha, T.H. and Bekheit, M.M., Mononuclear and polynuclear chelates of picolinoyldithiocarbazate. Chem.-pharm. Bull. 48, 914 (2000).

34. Lever, A.B.P., "Inorganic Electronic Spectroscopy", $2^{\text {nd }}$ ed., Elsevier, Amsterdam, (1984).

35. Raman, N., Ravichandran, S. and Thangaraja, C., Copper(II), cobalt(II), nickel(II) and zinc(II) complexes of Schiff base derived from benzil-2,4-dinitrophenylhydrazone with aniline. J. Chem. Sci. 116, 215 (2004).

36. El-Ayaan, U. and Abdel-Aziz, A. A. M., Synthesis, antimicrobial activity and molecular modeling of cobalt and nickel complexes containing the bulky ligand: bis[N-(2,6-diisopropylphenyl)imino] acenaphthene. Eur. J. Med. Chemi. 40, 1214 (2005). 


\section{تشييد وتوصيف طيفى فحص حرارى والنشاط ضد الميكروبات لليجاندات غير المتجانسة المحتويه فيه على نراتي وات الكبريت الأكسجين والنتروجين ومتراكبانها الفلزية لأيونات الكئه الكوبلت II الكادميوم II الزئيق II النزوجيد اليوانيل II

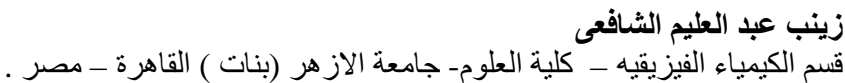

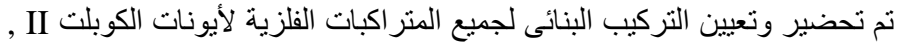

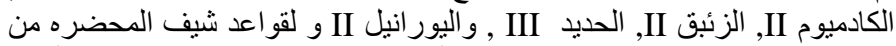

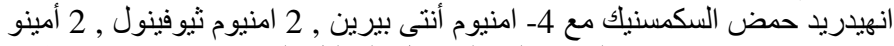

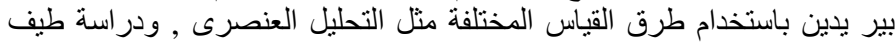

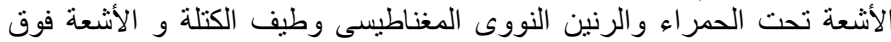

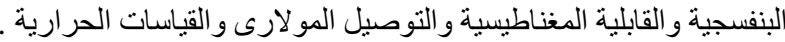

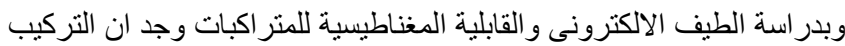
الهندسى الثمانى السطوح لكل المنر اكبات .

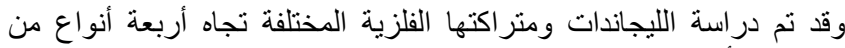

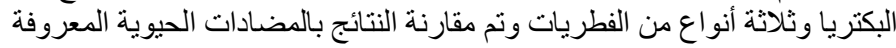

